\title{
Tarih Ders Kitaplarında Değerler ve Değer Aktarım Yaklaşımları ${ }^{*}$
}

\section{Values and Value Transfer Approaches in History Textbooks}

\section{Köksal MUÇ}

Marmara Üniversitesi, Eğitim Bilimleri Enstitüsü, E- Posta: koksal.muc@gmail.com

orcid.org/0000-0002-9016-3051

\section{Akif PAMUK}

Marmara Üniversitesi, Atatürk Eğitim Fakültesi, E- Posta: akifpamuk@hotmail.com orcid.org/0000-0002-8147-611X

Article Info

\begin{tabular}{|c|c|}
\hline Article Type & Research \& Theoretical \\
\hline Received & 11.09.2020 \\
\hline Accepted & 15.10 .2020 \\
\hline DOI & 10.17497/tuhed.793708 \\
\hline $\begin{array}{c}\text { Corresponding } \\
\text { Author }\end{array}$ & Köksal MUÇ \\
\hline Cite & $\begin{array}{l}\text { Muç, K., Pamuk, A. (2020). Tarih ders kitaplarında değerler ve değer } \\
\text { aktarım yaklaşımları. Turkish History Education Journal, 9(2), ss. 586- } \\
\text { 603. DOI: 10.17497/tuhed.793708 }\end{array}$ \\
\hline
\end{tabular}

* Bu çalışma ortaöğretim tarih ders kitaplarında değer aktarım yaklaşımları nelerdir? başlıklı yüksek lisans tezinden üretilmiştir. 
Öz: Değer, bireyin amaçları ve ihtiyaçları doğrultusunda olguya yüklediği belirli nitelik ve anlamlar ile belirlenen tavır ve davranışlar olarak tanımlanabilir. Değer, bireyin davranışlarına kaynaklık etmesinin yanında davranışları yargılamayı sağlayacak anlayışları da içerisinde barındırmaktadır. Değerlerin eğitim yoluyla yeni nesillere aktarılması ise değer eğitimine özel bir anlam yüklemiştir. Bireylerde öğretim programları vasıtasıyla davranış değişikliği öngören eğitim faaliyetleri içerisinde yer alan tarih dersleri, sadece geçmişin bilgisini öğretmekle kalmayıp değer aktarımını da içerisinde barındırmaktadır. Tarih dersleri, öğrencilere belli değerleri kazandırmakta ya da bu değerlerin sorgulanmasını sağlamaktadır. Bu bağlamda çalışmanın amacı Türkiye'de 2018 yılında gerçekleşen müfredat değişikliğinin ardından yenilenen ortaöğretim tarih ders kitaplarında yer alan değerlerin ve bu kitaplardaki değer aktarım yaklaşımlarının neler olduğunu ortaya çıkarmaktır. Araştırmada nitel araştırma desenlerinden durum çalışması kullanılarak doküman incelemesi yapılmıştır. Araştırmada 9, 10, 11. sınıf tarih ders kitapları ile 12. sınıf T.C. İnkılap Tarihi ve Atatürkçülük ders kitapları incelenmiştir. Ders kitaplarındaki değerler ve değer aktarım yaklaşımlarının neler olduğu ve ifade etmiş olduğu anlamlar betimsel analiz ve içerik analizi yapılarak tespit edilmiştir. Sonuç olarak ders kitaplarında yer alan kök değerlerin, evrensel ve geleneksel anlayış odaklı karakter eğitiminde yer alan değerlerden meydana geldiği ortaya çıkmıştır. Mevcut değerlerin aktarımında sıklıkla tercih edilen yöntemin, birçok değerin doğrudan öğrenciye aktarıldığı değerleri telkin etmek veya aşılamak olduğu tespit edilmiştir.

Anahtar Kelimeler: Değer, Değerler Eğitimi, Değer Aktarımı, Tarih, Tarih Eğitimi

\begin{abstract}
The value can be defined as the attitudes and behaviors determined by the specific qualities and meanings that the individual attributes to the phenomenon in line with the goals and needs of the individual. In addition to be a source of an individual's behaviors, value also includes understandings that will enable to judge behaviors. The transfer of values to new generations through education has given a special meaning to value education. History lessons, which are among educational activities that envision a behavioral change in individuals through education programs, not only teach the knowledge of the past but also include value transfer. History lessons bring certain values to students or enable them to be questioned. In this context, the purpose of the study reveals that after the renewed curriculum changes take place in Turkey in 2018 the value of secondary school history textbooks located and the value transfer approach in this book. In the research, 9th, 10th, 11th-grade history textbooks and 12th grade T.C. textbooks of Revolution History and Kemalism were examined. Values and value transfer approaches in textbooks and the meanings they expressed were determined by making descriptive analysis and content analysis. As a result, it is revealed that the root values in the textbooks are composed of the values included in the universal and traditional understanding-oriented character education. It has been determined that the method preferred frequently in the transfer of existing values is to suggest or instill values in which many values are directly transferred to the student.
\end{abstract}

Keywords: Value, Values Education, Value Transfer, History, History Education

\title{
Extended Summary
}

\section{Purpose}

This study aims to determine the values which can be considered as influential in the making of characteristics of individuals and societies, through high school history textbooks. 
Secondly, the article seeks to explore which value transfer approaches are used in conveying the values determined in the study. That said, in relation to the aims stated, the research also intends to identify how the compatibility/rapport between the curriculum and textbooks in relation to values has been materialized.

\section{Method}

In this study, qualitative methodology is used. The research design of the article is a case study that determined the values and the value transfer approaches used in transmitting these values. In this respect, data is collected through document analysis, and the Ministry of National Education's high school history textbooks are chosen as samples. The data analysis methods; descriptive analysis and content analysis are used to classify/sort and interpret the findings.

The sample of the research is the Ministry of National Education, which was renewed after the curriculum change in 2018 and prepared in accordance with the secondary education history course curriculum, 9- 10-11. class secondary education history textbooks and 12thgrade T.C. It is a textbook of Revolution History and Kemalism.

\section{Results and Discussion}

In this study, the values and the value transfer approaches used in transmitting these values and the meanings conveyed in the history textbooks are determined. Within this context, the frequencies of values in the textbooks illustrated that only "justice" in the $9^{\text {th }}$ grade history textbook, values of "justice" and "self-control" in the $10^{\text {th }}$-grade history textbook, values of "justice" and "patriotism" in the $11^{\text {th }}$-grade history textbook, and values of "altruism" and "patriotism" in the $12^{\text {th }}$-grade history textbook were evident. "Equality" is the other value with a higher frequency that is connected to core values [kök değer] that is stated in the curriculum.

It is seen that these values transferred in history textbooks vary based on textbooks and units and are not included in the curriculum as stated. This result coincides with the results of studies focusing on the relationship between history textbooks and values (Keskin, 2015; Yıldırım, 2017; Erkan \& Çoban, 2018). In addition, Erkan and Çoban (2018) found that the value of justice took first place in their research on the frequency of values in the 9th, 10th, and 11th-grade textbooks. In this study, the fact that the value that is widely used in textbooks is the value of justice shows that there is a parallelism between the two studies.

In the transfer of values, it has been determined that the most common approach in history textbooks is to suggest or instill values, and it is among the results of the study that the value analysis approach is rarely included. Trying to teach many of the values by using the method of inculcating or infusing values shows that certain values that are the goals of this method are expected to be internalized and accepted by the student without questioning (Akbaş, 2004). The fact that these values are given mostly through historical and literary stories shows the application example of traditional understanding-oriented character education (Ekşi \& Katilmış, 2011). 


\section{Conclusion}

According to Akbaş (2008), one of the duties assigned to educational institutions is to ensure that values are internalized by students with formal or implicit programs. In addition, considering that education aims to discipline students and contribute positively to their moral development, the values determined in the research and the preferred approaches support this situation.

In the relationship between values and history education, Dilek (2002) associated the social goals of history education with individual and social values. Demircioğlu (2014) stated that one of the objectives of traditional history education is to raise people who adopt the values and culture of the society. In the results of this study, the determination that many values are directly transferred in history textbooks taught at different levels supports the findings of both researchers. In addition, the view (Pamuk, 2009: 90) that values are used as a tool in a union that is tried to be formed within the framework of common national consciousness and common values through history education is similar to the results of this study.

Based on the results of the study, attention should be paid to the fact that the values are included in the textbooks as emphasized in the curriculum. In addition to values such as justice, sacrifice, and friendship, which are included in the units and subjects in the textbooks, values such as freedom and happiness (Bacanlı and Dombaycı, 2012) included in the value list of the United Nations Educational, Scientific and Cultural Organization (UNESCO) can also be included in the textbooks.

\section{Giriş}

Sosyal bilim, en geniş anlamıyla, toplum ve insanların davranış biçimleri ile çevremizdeki dünyanın bu davranış biçimlerinden nasıl etkilendiği üzerine yapılan çalışmaları içermektedir (Brewer, 2013: 21). Söz konusu davranış biçimlerinin anlamlandırılmasında ise toplumsal ve bireysel değerlerin ön plana çıktığı görülmektedir. Toplumsal yapının en temel bileşeni olan bireyler içinse değer, benlik algısının oluşmasının yanında dış dünyayı anlamlandırmada önemli bir yer tutmaktadır. Nitekim değer kavramının kişisel ve sosyal yaşamın anlaşılmasında ve ahlaka uygun olarak adlandırılabilecek şeyleri ifade ettiği konusunda bir fikir birliği olduğu (Kitwood, 1977) yapılan araştırmaların sonuçları arasındadır.

Toplumsal düzeni meydana getiren yapının bileşeni olarak değerlere bakıldığında ise, kültürel farklıııların temel hareket noktasını oluşturmaktadır. Mevcut kültürel yapının özelliklerini bireye aktararak devamlılığını ve sürdürülebilirliğini sağlamak için toplumlar, değerlerin aktarılmasını zorunlu görmektedir. Aktarımı yapılan değerler ve normlar makbul vatandaşı şekillendirmekte ve onu topluma uyumlu hale getirmektedir.

Bahsi geçen makbul vatandaşın inşasında saygı, sorumluluk, dürüstlük gibi anahtar değerlere odaklanıldığı görülür. Aynı zamanda değer aktarım pratiği formal ve örtük olarak 
okulun her alanına yayılmış durumdadır. Özellikle belirli değerlerin öğrenme sürecinde öğrencilerin karakterlerini oluşturmak için aktarıldığı (Leenders ve Veugelers, 2006) dikkati çekmektedir.

Öğrenme süreçlerindeki farklııılar, değer aktarım yaklaşımlarının çeşitlenmesini de beraberinde getirmiştir. Değer aktarım yaklaşımları öğrencilere değer kazandırmada kullanılan yöntemleri içermektedir. Temelde bu yaklaşımlar; telkin etme veya aşılama, değer analizi, değer açıklama ve ahlaki muhakeme (ahlaki ikilem) olarak adlandırılmaktadır (Yel ve Aladağ, 2009; Gültekin, 2014). Bu yaklaşımlar değer aktarımında farklı yollar izlese de temelde öznenin etken veya edilgen bir role sahip olmasıyla yakından ilgilidir. Bu bağlamda öznenin toplumsallaşmasında yaygın olarak kullanılan yaklaşım, toplumun belirlediği değer ve normların doğrudan aktarıldığı ve bireyin daha çok edilgen bir konumda yer aldığı değerleri telkin etme veya aşılama yaklaşımı olmaktadır. Buna ek olarak temelde öğrenciyi edilgen halden etken hale getiren değer analizi, değer açıklama ve ahlaki muhakeme yaklaşımları değer aktarımında kullanılan yaklaşımlar arasındadır (Muç, 2019).

Uygulama pratiklerinde çeşitlilik, makro boyutta bireyin uygun ve/ veya uyumlu hale getirilmesi, temelde eğitim ile değerleri ilişkili hale getirmektedir. Bireylerde istenilen yönde davranış değişikliğinden başlayarak toplumun varlığı ve mevcut kültürün devamlılığı için hayati bir önem atfedilen eğitim, değer aktarımında ve yeni nesillere değer kazandırmada temel bir aygıt olma görevini üstlenmiştir. Bunun yanında kaliteli bir eğitim içinde değerler eğitimi, öğrencilerin öğrenme ihtiyaçlarını gözeterek tüm pedagojinin merkezinde olmalıdır (Lovant ve Clement, 2008).

Pedagojik uygulamaların önemli bir bileşeni olan değerler aynı zamanda egemen söylemin makbul vatandaş tanımının özelliklerini de ifade etmektedir. Fakat bu özelliklerin eğitim yapısında dünyada meydana gelen devrimsel nitelikteki gelişmelerden etkilendiği söylenebilir. Özellikle sanayi devrimi sonrası ortaya çıkan, ampirist ve genellemeci bir yapıda olan pozitivist paradigmada, bireyden egemen toplum yapısında yer alan değer ve normları içselleştirmesi beklenmiştir. Buna karşın yorumlayıcı paradigmada ise bireylerin kendi değerlerini keşfetmesi öngörülmüştür (Altınbaş, 2012). Bu durum ise yeni bir çelişki alanını meydana getirmiştir.

Sözü edilen bu çelişkili durum hiç kuşkusuz Türk eğitim sistemi içinde de karşılık bulmuş, özellikle toplumsal değişim ve dönüşümün hızlı yaşandığı monarşik düzenden demokratik düzene geçişte, hangi değerlerin aktarılması gerektiğine dair tartışmalar gündeme gelmiştir. Bu bağlamda Cumhuriyet döneminde ilk olarak ders kitaplarından eski yönetim sistemine dair düşünce ve değerler çıkarılarak, yerine cumhuriyet rejiminin öğretileri ve değerleri yerleştirilmiş ve eğitimin temel amacı ulusal bilinci aşılamak haline gelmiştir (Aktekin, 2009). Bu durum işlevsel bir alan olan değerin, eğitimin diğer tüm alanlarıyla bir bütün olarak yapılandırıldığını göstermektedir.

Kolektif bir kimlik yaratmak ve daha çok makbul vatandaş yetiştirme şeklinde karşımıza çıkan değerler, Türk eğitim sistemi içerisinde kendine yer edinmiştir. Bu konuda en büyük pay kuşkusuz tarih derslerine ve tarih ders kitaplarına aittir. Tarih, insanlığın ortak hafızası, toplumların gelenek, görenek, örf ve adetlerinin sözlü ve yazılı olarak nesiller arası 
aktarılmasını sağlayan önemli bir disiplin olarak görülmektedir (Tokdemir, 2007). Bu bağlamda tarih ders kitapları sistem içerisinde gelenek, görenek, örf ve adetlerin yanı sıra değer aktarımı yapılması için tercih edilen önemli bir araç olmuştur.

Ayrıca tarih ders kitaplarında Türk milli eğitiminin amaç ve hedefleri doğrultusunda inşa edilen bilgi ve beceri temelli yapıda değerlere de yer verilmesi gereklilik olarak görülmekte (Erkan ve Çoban, 2018) bu bağlamda değerler ile tarih ders kitapları arasındaki bütünleşmiş ilişkiye dair vurgular söz konusudur.

\section{Türkiye'de Tarihsel Olarak Tarih Öğretimindeki Temel Eğilimler}

Türk Eğitim Sistemi içerisinde, Cumhuriyet rejimine geçişten itibaren tarihe ve tarih derslerine ve dolayısıyla ders kitaplarına özel bir anlam yüklenmiştir. Tarih ders kitapları rejimin ilk yıllarında Türk Tarih Tezi ekseninde ortaya atılan tezleri savunan içerikle karşımıza çıkmaktadır. Bu süreçte ulusal bilinci oluşturmak için pozitivist bilim algısının gücünden yararlanıldığı görülmüştür (Şimşek ve Yazıcı, 2013).

Tarih ders kitaplarında Türk Tarih Tezi ve etkileri uzun yıllar etkisini sürdürmüştür. Ancak 1940-50 ve 60'lı yıllar arasında tarih öğretimi hümanizm ve antik çağ konularının etkisi ile ders kitaplarında bu çağın değerlerine dikkat çekilmiştir. 1980'li yıllarda ortaya çıkan Türkİslam sentezi düşünce yapısı ise, Türk milli kültürü ile İslamiyet arasında yeni bir birey tipolojisi tasavvurunda bulunmuştur. Bir yanıyla tarih yazımında milli değerler ön plana çıkartılırken, bir yanıyla da İslam dininin değerlerinin aktarılması öngörülmüştür. Bu bağlamda makbul vatandaşa milli ve İslami değerleri bünyesinde barındıran yeni bir kimlik tanımlanmıştır (Şimşek ve Yazıcı, 2013; Örnek, 2020; Pamuk, 2009). Bu yeni kimlik tanımında da değerler önemini devam ettirmiştir.

1980'li yıllardan 2000'li yıllara gelindiğinde ise Türk eğitim sisteminin dayanmış olduğu pozitivist felsefenin kaynaklık ettiği davranışçı yaklaşım, 2007 yılından itibaren ortaöğretimde yerini postmodern ilkelere dayanan yapılandırmacı yaklaşıma bırakmıştır. Davranışçı yaklaşımın sonuç odaklıı̆̆ının aksine, süreç ve beceri temelli olan yapılandırmacı yaklaşım prensiplerince ders kitapları yenilenmiştir (Şimşek ve Yazıcı, 2013). Bu bağlamda tarih ders kitaplarında "adalet, insan haklarına saygı, yardımseverlik, dayanışma, eşitlik, dürüstlük vb." değerlere vurgu yapılmıştır (Ulusoy, 2010). Böylelikle yeniden yapılanma sürecinde değerlerin de yeniden yapılandırıldı̆̆ı göze çarpmaktadır.

Değerler eğitimi ile tarih dersleri arasında görülen bu ilişki, kendisini uygulanmakta olan öğretim programında da göstermiştir. Nitekim 2018 yılında Milli Eğitim Bakanlığı (MEB) tarafından oluşturulan ve yürürlüğe konulan “Ortaöğretim Tarih Dersi Öğretim Programı”nda değerler konusuna yer verilmiştir (MEB, 2018). Değerlerin sahip olduğu öneme ve uygulama yöntemlerine dair vurgular yapılmıştır.

2018 yılında hazırlanan 9, 10, 11. sınıf tarih ders kitapları ve 12. sınıf T.C. Inkılap Tarihi ve Atatürkçülük dersi için hazırlanan öğretim programında değerlere yapılan vurgu şöyledir; "öğretim programları salt bilgi aktaran bir yapıdan ziyade bireysel farklılıkları dikkate alan, değer ve beceri kazandırma hedefli, sade ve anlaşılır bir yapıda hazırlanmıştır" (MEB, 2018: 4). $\mathrm{Bu}$ ifade ile öğretim programının temel hedefleri tanımlanırken, değerlerin programın temel yapı taşlarından birini oluşturduğu dikkat çekmektedir. Bu bağlamda öğretim programı 
tanımlanırken değerler, beceri ve yetkinlikler çerçevesinde bütünleşmiş bir öğretim programı oluşturulduğu aktarılmaktadır.

Yine bu eksende programda değerler "toplumumuzun millî ve manevi kaynaklarından damıtılarak dünden bugüne ulaşmış ve yarınlarımıza aktaracağımız öz mirasımızdır" (MEB, 2018: 5) şeklinde tanımlanmaktadır. Öğretim programında yer alan "kök değerler" olarak tabir edilen değerlerin ise "adalet, dostluk, dürüstlük, öz denetim, sabır, saygı, sevgi, sorumluluk, vatanseverlik, yardımseverlik" değerleri olduğu görülmektedir (MEB, 2018: 6). Ayrıca bu kök değerlerin, süreçte tek başına verilebileceği gibi birlikte de verilebileceği aynı zamanda ilişkili olduğu düşünülen alt değerlerle beraber yer alacağı belirtilmektedir.

Öğretim materyalleri içerisinde değer yüklü olan tarih ders kitapları ile değerler arasındaki ilişkinin geçmişten bugüne değin varlığını koruduğu görülmektedir. Nitekim uygulanmakta olan 2018 tarihli ortaöğretim tarih dersi öğretim programında (MEB, 2018) değerlere ilişkin ifadeler bu ilişkinin niteliğine dair veriler sunmaktadır. Bu veriler ışığında ders kitaplarında hem değerlere hem de daha önce araştırma konusu yapılamayan değer aktarım yaklaşımlarına açıklık getirmek önem arz etmektedir. Ayrıca bu çalışma tarih öğretim programında tanımlanan değerlerin ders kitaplarına ne şekilde yansıtıldığını ortaya koyması açısından önem taşımaktadır. Bu bağlamda çalışmanın amacı Türkiye'de 2018 yılında gerçekleşen müfredat değişikliğinin ardından yenilenen ortaöğretim tarih ders kitaplarında yer alan değerlerin ve değer aktarım yaklaşımlarının neler olduğunu ortaya çıkarmaktır. Bu bağlamda araştırmanın problem cümlesini tarih ders kitaplarında değerler ve değer aktarım yaklaşımları nelerdir? sorusu oluşturmaktadır.

\section{Yöntem}

\section{Araştırma Deseni}

Araştırmada nitel araştırma yöntemi tercih edilmiştir. Nitel araştırma, yorumlayıcı materyal uygulamalarından oluşur. Bu uygulamalar dünyayı; alan notları, mülakatlar, konuşmalar, fotoğraflar, kayıtlar ve kendinize yazdığınız notları içeren bir temsiller serisine dönüştürür (Creswell, 2013). Nitel araştırmalarda özellikle sosyal bilimlerde yapılan araştırmalarda sıklıkla tercih edilen bir araştırma deseni ise durum çalışmasıdır. Durum çalışması sınırlı bir sistemin derinlemesine betimlenmesi ve incelenmesidir (Merriam, 2015). Ayrıca yine durum çalışmasını bir durumun, fenomenin veya sosyal birimin yoğun, bütünsel bir tanımı ve analizi olarak tanımlanmaktadır (Akt. Glennon, 2006: 35). Bu tanımlardan hareketle sınırlı sistem olarak nitelenen ders kitaplarında bir fenomen olan değerler, ders kitaplarında durum çalışması ile bütüncül olarak incelenerek veriler elde edilmiştir.

\section{Verilerin Toplanması ve Analizi}

$\mathrm{Bu}$ araştırmada veriler doküman analizi yapılarak elde edilmiştir. İstenen konu hakkında araştırmacıya bilgi temin eden yazılı materyallere doküman adı verilmektedir (Balcı, 2013). Bu doğrultuda 2018 yılında gerçekleşen müfredat değişikliğinin ardından yenilenen ortaöğretim tarih dersi öğretim program doğrultusunda hazırlanan ve MEB tarafından 
yayımlanmış 9, 10, 11. sınıf ortaöğretim tarih ders kitapları ile 12. sınıf T.C. İnkılap Tarihi ve Atatürkçülük ders kitaplarından veriler toplanmıştır. Ders kitapları üzerinden yürütülen bu çalışma etik kurulu onayı gerektirmemektedir.

Elde edilen veriler betimsel ve içerik analizine tabi tutulmuştur. Betimsel analiz, elde edilen verilerin araştırmacı tarafından tespit edilen temalara göre kısa özetler halinde yorumlanması ve değerlendirilmesini içeren bir veri analizi türüdür. Bu kapsamda betimsel analiz yoluyla ders kitaplarında değerler ve aktarım yaklaşımlarının neler olduğu tespit edilmiş ve kullanım sıklıklarına dair frekanslar elde edilmiştir. İçerik analizinde ise mevcut veri parçalanarak etkenden etkiye gitme yolu takip edilmektedir (Yıldırım ve Şimşek, 2013). Bu bağlamda araştırmada betimsel analizle tespit edilen değerlerin ve tercih edilen aktarım yaklaşımlarının hangi konularda, nasıl sunulduğu, hangi bağlamları içerdiğine dair içerik analizi yapılmıştır. Ayrıca araştırmanın geçerlik ve güvenirliğini sağlamak için uzman incelemesi yapılmıştır. Araştırma verileri, iki alan eğitimi uzmanı tarafından incelenmiş ve analiz kategorileri oluşturulmuştur. Araştırmacıların ve uzmanların oluşturduğu analiz kategorileri karşılaştırılmış ve görüş birliği sağlanmıştır (Creswell, 2013; Yıldırım ve Şimşek, 2013). Böylelikle tarih ders kitapları ile değerlerin ve aktarım yaklaşımlarının arasındaki ilişkiye dair çıkarımlarda bulunulmuştur.

\section{Bulgular}

Bu bölümde doküman incelemesi ile elde edilen bulgulara ve bu bulguların yorumlarına yer verilmiştir. Bu bağlamda tarih ders kitaplarında değerler ve değer aktarım yaklaşımları olmak üzere iki başlık altında incelenmiştir.

\section{Tarih Ders Kitaplarında Yer Alan Değerler}

Temelde geçmişin bilgisini sağlayan ve yeni nesillerin milli kimliğini ve aidiyetin inşasında rol oynayan önemli unsurların başında gelen tarih dersleri, içerisinde bireylerin karakterini oluşturacak değerleri barındırmaktadır. Tarih ders kitapları ise değer aktarımında önemli bir araç olma özelliği taşımaktadır. Bu bağlamda 2018 yılında yayımlanan tarih dersi öğretim programında belirtilen değerlerin tarih ders kitaplarında dağılımına ve kullanım sıklığına dair betimsel analiz tabloları aşağıda verilmiştir.

Tablo 1

9. Sınıf Tarih Ders Kitabında Değerler ve Frekansları

\begin{tabular}{llll}
\hline Kök Değerler & Frekans & Diğer Değerler & Frekans \\
\hline Adalet & 8 & Eşitlik & 3 \\
Vatanseverlik & 3 & Milli ve Toplumsal Kimlik & 2 \\
Dayanışma & 2 & Kültürel Miras & 1 \\
& & Milli Birlik ve Beraberlik & 1 \\
& & Millet Sevgisi & 1 \\
& & Cömertlik & 1 \\
& & Cesaret & 1 \\
\hline
\end{tabular}


Tablo 1'de görüldüğü gibi 9. sınıf tarih ders kitabında adalet kök değeri en fazla sıklıkta yer alırken, diğer değerlerden eşitlik ve milli ve toplumsal kimlik değerleri sıklıkla yer alan değerler olmuştur. Ancak değerlerin dağılımı ve konular içerisinde yer alışına dair öğretim programında yapılan vurgu tam anlamıyla karşılık bulmadığı, ancak bazı değerlerin diğer değerlerden daha çok yer aktarıldığı görülmektedir. Dağılım gösteren değerlerin ise daha çok ilk uygarlıklar ve ilk Müslüman Türk Devletleri konuları içerisinde yer bulduğu gözlenmiştir.

Değer dağılımına ilişkin yine 2018 yılında yayınlanan tarih dersi öğretim programında belirtilen değerlerin 10. sınıf tarih ders kitabındaki dağılımına ve kullanım sıklığına ise aşağıdaki tabloda verilmiştir.

Tablo 2

10. Sınıf Tarih Ders Kitabında Değerler ve Frekansları

\begin{tabular}{llll}
\hline Kök Değerler & Frekans & Diğer Değerler & Frekans \\
\hline Adalet & 11 & Eşitlik & 4 \\
Öz Denetim & 9 & Barış & 2 \\
Sevgi & 7 & Cömertlik & 2 \\
Yardımseverlik & 4 & Cesaret & 2 \\
Dürüstlük & 4 & Evrensellik & 2 \\
Dayanışma & 3 & Milli ve Toplumsal Kimlik & 1 \\
Fedakârlık & 2 & Özgürlük & 1 \\
Sorumluluk & 2 & Alçak Gönüllülük & 1 \\
Dostluk & 1 & Sadakat & 1 \\
Vatanseverlik & 1 & Özveri & 1 \\
Saygı & 1 & Temizlik & 1 \\
& & Merhamet & 1 \\
& & İilik & 1 \\
& & Hoşgörü & 1 \\
\hline
\end{tabular}

Tablo 2'de görüldüğü gibi 10. sınıf tarih ders kitabında öğretim programda yer alan "değerlerimiz, ayrı bir program veya öğrenme alanı, ünite, konu vb. olarak görülmemiştir" (MEB, 2018: 6) ifadeye uygun olarak bir önceki ders kitabına göre, birçok değere yer verildiği görülmektedir. Bu ders kitabında ağırlıklı olarak Osmanlı Devleti'nde yönetim anlayışından izlediği politikalara kadar ayrıntılı bilgilerin yer aldığı, bu bakımdan birçok değer yüklü ifadelerin yer aldığı gözlemlenmiştir.

10. sınıf tarih ders kitabında değerlerin ünite ve konular içinde dağılımına ve sıklığına ilişkin durum böyle iken 11. sınıf ders kitabındaki durum ise aşağıdaki tabloda verilmiştir.

Tablo 3

11. Sınıf Tarih Ders Kitabında Değerler ve Frekansları

\begin{tabular}{llll}
\hline Kök Değerler & Frekans & Diğer Değerler & Frekans \\
\hline Adalet & 4 & Eşitlik & 4 \\
Vatanseverlik & 4 & Cesaret & 1 \\
Saygı & 2 & Çalışkanlık & 1 \\
Dayanışma & 1 & & \\
Fedakârlık & 1 & & \\
\hline
\end{tabular}


Tablo 3'te görüldüğü üzere 11. sınıf ders kitabında daha az değere yer verildiği görülmektedir. Bu ders kitabında ise dünyada meydana gelen Sanayi Devrimi, Fransız İhtilali gibi olaylar ve bu olayların Osmanlı Devleti'ne etkilerinin ele alındığı görülmektedir. Bu bağlamda 9. sınıf tarih ders kitabıyla benzer bir şekilde bu ders kitabında da değerlere yapılan vurgunun yeterli seviyede olmadığı görülmüştür.

11. sınıf tarih ders kitabında değerler ve frekanslarına dair yapılan incelemelerin ardından 12. sınıf T.C İnkılap Tarihi ve Atatürkçülük ders kitabında değerler ve kullanım sıklıkları tablosu aşağıda verilmiştir.

Tablo 4

12. Sınıf T.C İnkılap Tarihi ve Atatürkçülük Ders Kitabında Değerler ve Frekansları

\begin{tabular}{llll}
\hline Kök Değerler & Frekans & Diğer Değerler & Frekans \\
\hline Fedakârlık & 12 & Milli Birlik ve Beraberlik & 3 \\
Vatanseverlik & 12 & Eşitlik & 2 \\
Sevgi & 4 & Milli Kimlik & 2 \\
Adalet & 3 & Milli Bilinç & 1 \\
Dostluk & 3 & Yenilikçilik & 1 \\
Öz Denetim & 3 & Açık Görüşlülük & 1 \\
Yardımseverlik & 3 & Kahramanlık & 1 \\
Dayanışma & 2 & Özveri & 1 \\
Sabır & 1 & & \\
Sorumluluk & 1 & & \\
\hline
\end{tabular}

Tablo 4'te ise incelenen ders kitaplarına göre değerlerin çeşitlilik gösterdiği özellikle fedakârlık ve vatanseverlik değerlerinin yüksek frekansa sahip olduğu görülmektedir. Bu dersin konularında milli mücadele ve Cumhuriyet rejimine geçiş ağırlıklıdır. Bu bağlamda özellikle milli mücadele konularında değerlere vurgu yapıldığı gözlenmiştir.

Yukarıdaki tablolarda her bir ders kitabında verilmek istenen değerleri, bu değerlerin dağılımını ve frekansları görmek mümkündür. Bu bağlamda ortaöğretim tarih dersi öğretim programında belirtilen kök değerlerin "adalet, dostluk, dürüstlük, öz denetim, sabır, saygı, sevgi, sorumluluk, vatanseverlik, yardımseverlik" tümü ders kitaplarında dağılım farklılıkları gösterse de geneli itibarıyla yer almıştır. Bu değerlerden en yüksek frekansı gösteren değerlerin başında "adalet, fedakârlık, vatanseverlik, öz denetim" in geldiği görülmektedir. Tablolarda "diğer değerler" olarak ifade edilen değerlerin ise yine öğretim programında kök değerler ile bağlantılı "diğer değerler" olarak tanımlanan değerler olduğu görülmektedir. Frekansları en yüksek bağlantılı diğer değerlerin; "eşitlik, milli birlik ve beraberlik, cömertlik, cesaret, kültürel miras" değerleri olduğu tespit edilmiştir. Değerlerin öğretim programıyla uyumlu olarak ayrı bir konu ve ünite olarak değil, konularla bağlantılı olarak, konuların içerisinde aktarılmaya çalışıldığı da gözlenmiştir.

Betimsel analiz tablolarının geneline bakıldığında ise tüm ders kitaplarında en yaygın kullanılan kök değerin adalet değeri olduğu görülmektedir. 9. sınıf tarih ders kitabında; (MEB, 2018: 104) "Törenin en önemli değeri olan adalet de bu yüzden mülkün yani devletin temeli kabul edilmiştir. Devlet teşkilatlanmasında düzenleyici bir role sahip olan töre, kağanın hem 
keyfî hareket etmesini engellemiş hem de halkına adil davranması için bir kontrol mekanizması olmuştur." ifadelerinde adalet değerinin tek bir kök değer olarak verildiği örneğine de rastlanılmaktadır. Buradaki kullanımından hareketle adalet değerlerinin hem kültürel hem de idari yapıdaki işlevlerinin belirtildiği gözlenmektedir.

Kök değerler olarak seçilen değerler, makbul bir vatandaşın sahip olması istenilen temel değerleri de ifade eder. Fakat bu durum genel olarak örnek gösterme şeklinde veya dikkat çekme yoluyla da gerçekleşebilmektedir. Bu bağlamda adalet değeri kullanımının bir başka örneğine 10. sınıf tarih ders kitabında şu cümlelere rastlanılmaktadır (MEB, 2018: 177): "Siyasetnamelere göre devlet idaresinde adalet anlayışı en başta gelen erdemdir. Osmanlı Devleti'nde adaleti sağlamak padişahın yerine getirmesi gereken en önemli görevdir. Adaletle korunan reaya sayesinde güçlü devletler ortaya çıkmıştır." Metinde görüldüğü gibi doğrudan adalet değerine ve onun idari bir görev olduğuna vurgu yapılmıştır.

Makbul vatandaş yetiştirme, değerler ve değer aktarımı konusuyla yakından ilgili olmakla beraber, ders kitapları bu konuyu aktarmada bir araç olarak kullanıma müsait bir yapıdadır. Egemen söylemin içinde bir araç olarak var olan tarih ders kitapları ise bu durumun örneklerini görmemiz açısında önemli bir yer tutar. 11. sınıf tarih ders kitabında (MEB, 2018: 154) yer alan: "Osmanlı Devleti yönetim anlayışının temelinde savunma, güvenlik ve adalet vardır." cümlesinde verilmek istenen ve en sık kullanılan adalet değeri iken, yine aynı ders kitabında "Devletler eğitim sistemleri ve askerî teşkilatları sayesinde aynı üniformayı giyen, aynı marşı söyleyen, aynı dili konuşan, disiplinli, vatansever, üretken ve devletine sadık vatandaşlar yetiştirdiler." örneğinde aktarılan değerin vatanseverlik olduğu görülmektedir.

Değer aktarımı yapılması bir tarafıyla makbul vatandaşın özelliklerini görmemize de imkân sağlamaktadır. Aktarılan değerlere yapılan vurgu ders kitapları arasında farklılıklar göstermiştir. Bu bağlamda 12. sınıf T.C. İnkılap Tarihi ve Atatürkçülük ders kitabında diğer ders kitaplarından farklı olarak en sık kullanılan değerlerin fedakârlık ve vatanseverlik olduğu görülmektedir. Bu durumun ders kitabında Kurtuluş Savaşı konularının ağırlıklı olmasından kaynaklandığı düşünülmektedir. 12. sınıf T.C. İnkılap Tarihi ve Atatürkçülük ders kitabında (MEB, 2018: 59) yer alan Kara Fatma-Fatma Seher Erden (1888-1955) adlı biyografi bu duruma örnek niteliği taşımakta olup ders kitabındaki bazı cümleler şu şekildedir:

Erzurum'da doğdu. Subay Derviş Bey'le evlenip Balkan Savaşı'na katıldı. Dünya Savaşı'nda 9-10 kadınla Kafkas Cephesi'ne gitti. Eşleri Ermenilerce şehit edilmiş kadınlarla Ermenilere karşı çarpıştı. Millî Mücadele döneminde oğlu, kızı ve kardeşleriyle beraber Bursa ve İzmit'in düşman işgalinden kurtarılması için çalıştı. 300 kişiyi aşkın müfrezesiyle Sakarya ve Başkomutan Meydan Muharebeleri' ne katıldı. Üsteğmen rütbesiyle emekli oldu. Emekli 1954'te TBMM'ce kendisine tekrar aylık bağlandı. Ertesi yıl Erzurum'da öldü.

Örnekte görüldüğü gibi kişi biyografisi üzerinden fedakârlık ve vatanseverlik değerlerine dikkat çekildiği görülmektedir. Bu durum 1980'li yıllarda tarih derslerinin amaçları tanımlanırken ifade edilen bazı şahsiyetlerin özelliklerinin ve değerlerinin ön planı çıkarılması anlayışının devamı niteliğindedir. 


\section{Tarih Ders Kitaplarında Değer Aktarım Yaklaşımları}

Araştırma bulgularından hareketle ortaöğretim tarih ders kitaplarının birçok değer barındırdığı görülmektedir. Bu kapsamda tarih derslerinin ve ders kitaplarının değerler ile yakından ilişkisini görmek mümkün olmuştur. Ancak bu değerlerin hangi değer aktarım yaklaşımları kullanılarak aktarıldığı yine değerler kadar önem taşımaktadır. Nitekim değer aktarım yaklaşımlarındaki değer kazanımında önemli bir role sahiptir. Bu bağlamda 9, 10, 11 ve 12. sınıf tarih ders kitaplarından değer aktarım yaklaşımlarına dair elde edilen betimsel analiz tablosu aşağıda sunulmuştur.

\section{Tablo 5}

Tarih Ders Kitaplarında Değer Aktarım Yaklaşımları ve Frekansları

\begin{tabular}{|c|c|c|c|c|}
\hline Yaklaşımlar & $\begin{array}{l}\text { 9. Sinif- } \\
\text { Frekans }\end{array}$ & 10. Sinıf- Frekans & $\begin{array}{l}\text { 11. Sinif- } \\
\text { Frekans }\end{array}$ & 12. Sınıf- Frekans \\
\hline $\begin{array}{l}\text { Değerleri Telkin Etmek } \\
\text { / Aşılamak }\end{array}$ & 14 & 34 & 17 & 32 \\
\hline Değer Analizi & 4 & 3 & - & 3 \\
\hline Değer Açıklama & - & - & - & - \\
\hline Ahlaki Muhakeme & - & - & - & - \\
\hline
\end{tabular}

Tablo 5'te 9, 10, 11 ve 12. sınıf tarih ders kitaplarında tercih edilen değer aktarım yaklaşımları ve frekansları gösterilmiştir. Tablodan anlaşılacağı üzere tüm sınıflarda en çok tercih edilen değerleri telkin etmek/aşılamak yaklaşımıdır. Bu durumun başlıca nedeni, değerleri telkin etmek veya aşılamak yönteminin, geleneksel değer eğitimi yaklaşımlarında, değeri öğretmen tarafından sunuş yoluyla sunmanın kolaylığıdır. Nitekim telkin yoluyla ders kitabında bulunan değerler doğrudan öğretmen vasıtasıyla öğrencilere aktarılmaktadır. Bu durumda davranışa dönüştürmesi beklenen değer/ değerler üzerine vurgu yapılır. Dolayısıyla MEB'in 2018 yılında yayımladığı ortaöğretim tarih dersi öğretim programında belirtilen birçok değer, bu yaklaşımla aktarılmıştır. Ders kitaplarında kullanımına rastlanan diğer yaklaşım ise değer analizi yaklaşımıdır. Değer analizi ise değerin öğrenci tarafından keşfine yönelik uygulanan, daha bilişsel süreçleri içeren bir yaklaşımdır. Tarih ders kitaplarında bu iki yaklaşımın örnekleri görülmüştür.

Ders kitaplarında en fazla tercih edilen yaklaşım olan Telkin etme veya aşılamak yaklaşımı, formal olarak belirlenmiş değerin aktarılmasıyla, bir konunun açıklamasında, önem ve işlevinde yer bulmaktadır. Nitekim 9. sınıf tarih ders kitabında (MEB, 2018: 104) yer alan: "Törenin oluşumunda; kut anlayışı ile kağanlar tarafından konulan kurallar, kurultaylarda alınan kararlar ve kağanın iradesiyle toplum içinde yavaş yavaş oluşan gelenekler etkili olmuştur. Getirilen kuralların adalete uygun olmasına dikkat edilmiştir. Kağanlar da dâhil olmak üzere bu töreye herkesin uyması zorunludur." metninde görüldüğü üzere adalet değerine telkin edici bir yöntemle vurgu yapılmaktadır. Öyle ki değerin yönetim erkinin yanı sıra toplumsal düzenleyicilik rolü üzerinde etkisine dikkat çekilmiştir.

Değerlerin doğrudan aktarımını amaçlayan telkin etme veya aşılamak yaklaşımının, ders kitaplarında konularla bağlantılı anı, biyografi ve şiir türleri içinde yer aldığı 
görülmektedir. Nitekim 10. sınıf tarih ders kitabında (MEB, 2018: 177) yer alan aşağıdaki şiirle adalet değerinin doğrudan aktarıldığını görmek mümkündür:

“Uzun ömür ve adalet ikiz kardeştirler,

Akıl sahipleri böyle haber verdiler.

Ebedilik adalet ve hakla olur,

Zulüm ile şahlık, rüzgâr ile lamba gibidir. “

Telkin etmek veya aşılamak yaklaşımının tercih edilmesinde önemli pragmatik amaçlar bulunmaktadır. Daha çok pozitivist yaklaşımla ilişkili olan bu yaklaşım, özellikle siyasi tarih konularının yoğunluk gösterdiği ders kitaplarında sık kullanıldığı göze çarpmaktadır. Bu bağlamda 11. sınıf tarih ders kitabında (MEB, 2018: 163) sadece bu yaklaşımın kullanılması bu duruma örnek oluşturmaktadır. Örnek vermek gerekirse: "Osmanlıcılık fikri anlatılırken, eşitlik değeri; "Osmanlı Devleti sınırlarında yaşayan Müslim, gayrimüslim halka yeni haklar vererek aralarında eşitlik sağlamak amacıyla Osmanlıcılık fikri benimsenmişti. Din, dil, ırk ayrımı yapmadan büyük bir Osmanlı milleti oluşturmak temel amaçtı." metninde görüldüğü gibi değerin doğrudan içselleştirme amacıyla telkin yoluyla verildiği göze çarpmaktadır.

Telkin etmek veya aşılamak yaklaşımı değerlerin aynı metin içinde sayıca birden fazla şekilde verilmesine olanak sağlamaktadır. Bu nedenle ders kitaplarında kullanım sıklığının bir sebebi olarak bu da görülebilir. Bu duruma örnek oluşturacak nitelikte 12. sınıf T.C. İnkılap Tarihi ve Atatürkçülük ders kitabında (MEB, 2018: 130) yer alan:

Atatürkçü düşünce, egemenliğin millete ait olduğunu savunur. Türk milletinin vatan ve millet sevgisi etrafında şekillenmesini öngörür. Bu bağlamda millî tarihin ve Türk dilinin millet bilinci oluşturmadaki önemini önceleyerek yapılan inkılaplarla Türk millî kültürünün unsurlarını geliştirmeyi hedefler. Böylece kendi millî kimliğinin farkında olan Türk milletinin dünya milletleri arasında bağımsız ve özgür yaşama idealini gerçekleştirmeye çalışır. Bunun yanında kendi millî kültürüne sahip çıkacak olan Türk insanından çağdaş dünyanın değerlerini takip etme ve millî kültürünü çağdaş değerlerle kaynaştırma hedefini de gösterir. Devletin yapısını ve sosyal hayatı çağdaşlaştırmaya yönelik inkılaplarla Türk milletini medeni dünyanın bir parçası hâline getirmeyi hedefler. Böylece Türkiye, çağdaş ve millî değerler doğrultusunda millî birlik ve beraberliğini ülke bütünlüğü çerçevesinde gerçekçi şartlarda hayata geçirme imkanına kavuşmuş olacaktır.

Metinde görüldüğü gibi vatanseverlik değerinin yanında milli bilinç, milli birlik ve beraberlik değerleri doğrudan telkin etme yaklaşıma uygun bir şekilde verilmiştir. Böylelikle frekans tablosunda dikkati çeken değerlerin birçoğu bu yaklaşımla öğrencinin değerleri görerek önemine dair vurguyu anlaması üzerine şekillenmiştir.

Değerleri telkin etmek veya aşılamak yaklaşımın yanı sıra tablo 5 'te görüldüğü gibi değer analizi yaklaşımı ders kitaplarında tercih edilen diğer bir diğer yaklaşım olmuştur. Değer analizi, telkin etmek veya aşılamak yaklaşımına göre daha çok değerin keşfine yönelik olarak bireysel bir süreci ifade eder. Bu bakımdan değerlerin açıkça verilmesinden ziyade öğrencinin değeri keşfetmesi sağlanmaktadır. Bu duruma örnek olarak 9. sınıf tarih ders kitabındaki (MEB, 
2018: 32) tartışalım bölümünde; İbrahim Kafesoğlu'nun “Medeniyet, milletlerarası ortak değerler seviyesine yükselen anlayış, davranış ve yaşama vasıtalarının bütünüdür. Bu ortak değerlerin kaynağı kültürlerdir." sözüyle medeniyet kavramının tanımı üzerinden, "Medeniyet tanımında yer alan milletlerarası ortak değerler neler olabilir?" sorusuyla öğrencilere konu tartıştırılarak olası değerlerin keşfettirilmeye çalışıldığı görülmektedir.

Değer analizi yaklaşımında; öğrencinin, öğretmenin müdahalesine maruz kalmadan ilgili kanıta göre kendi zihinsel süreçlerini kullanarak değerleri keşfetmesi, yaklaşımın temelini oluşturmaktadır. Bir başka değer analizi örneğini 10. sınıf tarih ders kitabında (MEB, 2018: 155) yer alan; "Ispanyada'ki Müslüman ve Yahudilere Yardım Edilmesi" metninde net olarak ifade edilmeden birçok değere yer verildiği ve metnin sonunda sorulan "Ispanya' daki Müslüman ve Yahudilere yardım edilmesi, Osmanlı Devleti'nin hangi özelliğini ortaya koymaktadır?” sorusu oluşturmaktadır. Bu soru ile öğrencilerin olası değerleri bulması amaçlanmaktadır.

Değerleri öğrencinin keşfetmesi için ders kitaplarında özel bölümler hazırlandığı görülmektedir. Özellikle "Değerlendirelim, Tartışalım ve Oku- Yorum” gibi bölümlerde değer analizi yaklaşımına yer verildiği görülmektedir. Bu durumun bir örneğini 12. sınıf T.C. İnkılap Tarihi ve Atatürkçülük ders kitabında (MEB, 2018: 208) yer alan “Küçük Rum Kız" yer alan:

Kıbrıs Barış Harekâtı'nda görev alan Zeynep hemşire Türk askerinin yaralarının sarılmasında en ön cephelerde yer aldı. Bir gün Türk askeri kendisine bir Rum kızının bulunduğunu kendisinin ilgilenmesini istedi. Zeynep Süngü 5 yaşındaki Rum çocuğa annelik yaptı. O günleri anlatan Zeynep hemşire: "Çocuk feryat figan ağlıyordu. Düşünsenize savaşın ortasında tek başına kalmış anne baba yok ortada. Onu kucağıma aldım sevdim. Bir müddet sonra kızı BM askerine verdik. Kız ağladı askerine gitmek istemedi. Askerin kucağında bana ellerini açtı.

Metinde değerlerin keşfedilmesi için öğrencilere sorulan; “Kore Savaşı'ndaki Koreli küçük kız Ayla olayını ve Kıbrıs Barış Harekatı'nda Zeynep hemşirenin başından geçen küçük Rum kız olayını karşılaştırarak Türklerin savaşta bile yaşattığı insani değerleri yorumlayınız." sorusuyla öğrencilerden değerleri keşfetmeleri beklendiği anlaşılmaktadır.

\section{Sonuç}

Araştırmanın sonuçlarına göre en yaygın kullanılan kök değerler; 9. sınıf tarih ders kitabında sadece adalet, 10. sınıf tarih ders kitabında en yaygın değerin adalet olmasının yanı sıra öz denetim değeri, 11. sınıf tarih ders kitabında ise yine adalet değeri ve beraberinde vatanseverlik değeri, 12. sınıf T.C. İnkılap Tarihi ve Atatürkçülük tarih ders kitabında fedakârlık, vatanseverlik değerlerinin yaygın kullanımı tespit edilmiştir. Kök değerlerin yanında öğretim programında belirtildiği gibi kök değerler ile bağlantılı diğer değerlerden en yüksek frekansa sahip değer eşitlik değeri olmuştur.

Tarih ders kitaplarında aktarımı yapılan bu değerlerin, ders kitapları ve üniteler bazında değişiklik gösterdiği ve öğretim programında belirtildiği şekliyle yer almadığı görülmektedir. Bu sonuç tarih ders kitapları ve değerler arasındaki ilişkiye odaklanan çalışmalarda (Keskin, 
2015; Yıldırım, 2017; Erkan ve Çoban, 2018) ders kitaplarında değer dağılımının sağlıklı şekilde yansıtılamadığı sonuçlarıyla örtüşmektedir. Ayrıca yine Erkan ve Çoban (2018) 9, 10 ve 11. sınıf ders kitaplarında değerlerin ne sıklıkla yer aldığı üzerine yapmış olduğu araştırmada ilk sırada adalet değerinin yer aldığını tespit etmişlerdir. Bu araştırmada da ders kitaplarında yaygın kullanıma sahip olan değerin adalet değeri olması iki araştırma arasında paralellik olduğunu göstermektedir.

Değerler söz konusu olduğunda Mills'in (2000, akt. Pamuk, 2007: 2) ifade ettiği "sosyal bilimler içerisinde yer alan değerler batı toplumlarında yaratılmış değerler arasından seçilmiş değerlerdir" sözü akıllara gelmektedir. Ders kitaplarında aktarılan değerlerin daha çok evrensel değerler olması (adalet, dostluk, dürüstlük vb.) bu duruma destekler niteliktedir. Üstel'in (2016) makbul bir vatandaş olmak için gerekli özellikleri değerlerle ilişkilendirildiği görülmektedir. Bu doğrultuda ders kitaplarında tespit edilen kök değerler ve ilişkili diğer değerler vasıtasıyla makbul vatandaşın sahip olması gereken özelliklerinin ve niteliklerinin belirlendiği görülmektedir.

Değerlerin aktarımında ise tarih ders kitaplarında en yaygın kullanılan yaklaşımın değerleri telkin etmek veya aşılamak olduğu tespit edilmiş ve bunun haricinde nadir de olsa değer analizi yaklaşımına yer verildiği araştırmanın sonuçları arasındadır. Değerlerin birçoğunun, değerleri telkin etmek veya aşılamak yöntemi kullanılarak öğretilmeye çalışılması, bu yöntemin amaçlarında olan belirli değerlerin içselleştirilmesi ve öğrenci tarafından sorgulanmadan (Akbaş, 2004) kabul edilmesinin beklendiğini göstermektedir. Bu değerlerin daha çok tarihi ve edebi hikâyeler üzerinden veriliyor olması geleneksel anlayış odaklı karakter eğitiminin de (Ekşi ve Katılmış, 2011) uygulama örneğini göstermektedir. Bu durum, makbul vatandaşın inşasını mümkün kılan bir yapıyı da ifade etmektedir.

Değer analizi yaklaşımının daha çok değeri keşfettirmeye yönelik ve sorgulama amaçlı bir yaklaşım olduğu düşünüldüğünde, ders kitaplarında belirli metinlere veya görsellere sorular sorularak bu yaklaşımın kullanıldığı görülmüştür. Bu durum öğrencinin metinlerde veya görsellerde değerlerin neler olabileceğine dair zihinsel süreçleri işin içine katması ile gerçekleşmektedir. Bu yaklaşımla ortak değerlerden ziyade bireysel değerler ön plana çıkmaktadır.

Eğitim kurumlarına yüklenen görevlerden biri Akbaş’a (2008) göre formal veya örtük programlar ile değerlerin öğrenciler tarafından içselleştirmelerini sağlamaktır. Ayrıca eğitimin, öğrencileri disipline etmek ve ahlaki gelişimlerine olumlu yönde katkı sağlamak amacı olduğu düşünüldüğünde, araştırmada tespit edilen değerler ve tercih edilen yaklaşımlar bu durumu destekler niteliktedir.

Demircioğlu ve Tokdemir (2008) eğitim faaliyetleri içerisinde yer alan tarih eğitimini vatandaşlık ve değer eğitimini destekleyebilecek önemli bir alan olduğu ifade etmekte, nitekim ders kitaplarında vatanseverlik, milli birlik ve beraberlik, milli bilinç, milli irade gibi değerlerin doğrudan ders kitaplarında yer alması bu durumu desteklemektedir.

Değerler ile tarih eğitimi arasındaki ilişkide Dilek (2002), tarih eğitiminin sosyal amaçlarını bireysel ve toplumsal değerlerle ilişkilendirmiştir. Demircioğlu (2014) ise geleneksel tarih eğitimi amaçlarından birinin toplumun değerlerini ve kültürünü benimseyen kişilerin 
yetiştirilmesi olduğunu belirtmiştir. Bu araştırmanın sonuçlarında farklı kademelerde okutulan tarih ders kitaplarında birçok değerin doğrudan aktarıldığının tespit edilmesi her iki araştırmacının tespitlerini destekler niteliktedir. Ayrıca değerlerin tarih eğitimi aracılığıyla ortak ulus bilinci ve ortak değerler çerçevesinde oluşturulmaya çalışılan bir birliktelikte araç olarak kullanıldığı görüşü (Pamuk, 2009: 90) bu araştırmanın sonuçları ile benzerlik göstermektedir.

Araştırmanın sonuçlarında hareketle değerlerin öğretim programında vurgulandığı şekliyle ders kitaplarında yer almasına dikkat edilmelidir. Ders kitaplarında ünite ve konular içerisinde yer alan adalet, fedakârlık, dostluk gibi değerlerin yanında Birleşmiş Milletler Eğitim, Bilim ve Kültür Örgütü (UNESCO) değer listesinde yer alan özgürlük, mutluluk (Bacanlı ve Dombaycı, 2012) gibi değerlere de ders kitaplarında yer verilebilir.

Değer aktarım yaklaşımlarında değerleri telkin etmek veya aşılamak ile değer analizinden farklı olarak ahlaki muhakeme ve değer açıklama yaklaşımları için ders kitaplarına çeşitli materyaller eklenmesi ve tarih öğretmenlerine veya öğretmen adaylarına ders kitaplarındaki değerlerin nasıl aktarılabileceğine yönelik eğitimlerin verilmesi değer öğretimini daha etkili bir hale getirebilir.

\section{Kaynakça}

Akbaş, O. (2004). Türk Milli Eğitim sisteminin duyuşsal amaçlarının ilköğretim II. kademedeki gerçekleşme derecesinin değerlendirilmesi (Yayımlanmamış doktora tezi). Gazi Üniversitesi Eğitim Bilimleri Enstitüsü, Ankara.

Akbaş, O. (2008). Değerler eğitimi akımlarına genel bir bakış. Değerler Eğitimi Dergisi, 6(16), s.9-27.

Aktekin, S. (2009). Türkiye'de tarih eğitimi. S. Aktekin, P. Harnett, M. Öztürk ve D. Smart (Edt.), Çok Kültürlü Bir Avrupa Için Tarih ve Sosyal Bilgiler Eğitimi (s. 27-43) Ankara: Harf Eğitim.

Altınbaş, M. E. (2012). Bireycilik ve toplumculuk tartışmaları bağlamında değerler eğitimi yaklaşımları, Değerler Eğitimi Dergisi, 10(24), s.31- 54

Bacanlı, H. ve Dombaycı, M. A. (2012). Değer boyutlandırma yaklaşımı. Il. Uluslararası Değerler ve Eğitimi Sempozyumu'nda sunulan bildiri. İstanbul. 20.05.2020 tarihinde https://docplayer.biz.tr/18619260-Deger-egitiminde-deger-boyutlandirmayaklasimi.html adresinden alınmıştır.

Balcı, A. (2013). Sosyal bilimlerde araştırma. Ankara: Pegem Akademi.

Brewer, J.D. (2013). The public value of the social sciences an interpretative essay. Bloomsbury Academic, DOI: 10.5040/9781472545121

Creswel, John W. (2013). Nitel araştırma yöntemleri, beş yaklaşıma göre nitel araştırma ve araştırma desenleri (Bütün M. ve Demir S.B, Çev.). Ankara: Siyasal. 
Demircioğlu, i.H. ve Tokdemir, M.A. (2008). Değerlerin oluşturulması sürecinde tarih eğitimi; Amaç, işlev ve içerik, Değerler Eğitimi Dergisi, 6(15), s.69-88.

Demircioğlu, i.H. (2014). Tarih öğretiminde öğrenci merkezli yaklaşımlar. Ankara: Anı.

Dilek, D. (2002). Tarih derslerinde öğrenme ve düşünce gelişimi. Ankara: Pegem Akademi.

Erkan S. ve Çoban, A. (2018). Değerler Açısından Tarih Öğretim Programları ve Ders Kitaplarının Incelenmesi, 21. Yüzyılda Eğitim ve Toplum, 7(21), s.771- 789.

Ekşi, H. ve Katılmış, A. (2011). Karakter eğitimi el kitabı. Ankara: Nobel.

Glennon, D. S. (2006). A case study analysıs of a character educatıon program, Published doctoral thesis, Capella University, ProQuest Dissertations Publishing, United States

Gültekin, F. (2014). Tarih öğretiminde değerler. M. Safran (Edt.) Tarih Nasıl Öğretilir? (s. 152159) İstanbul: Yeni İnsan.

Keskin, Y. (2015). Tarih dersi öğretim programı ve ders kitaplarında değerler eğitimi. TurkishStudies, 10(7), s. 659-674. DOI: http://dx.doi.org/10.7827/TurkishStudies.8234

Kitwood, T. (1977) What does 'having values' mean? Journal of Moral Education, 6(2), s.8189, Doi: 10.1080/0305724770060202

Leenders, H. Veugelers, W. (2006). Different perspectives on values and citizenship education. Curriculum and Teaching, 21(2), s. 5-20. DOI:10.7459/ct/21.2.02

Lovat T. ve Clement N.(2008) Quality teaching and values education: coalescing for effective learning, Journal of Moral Education, 37(1), s.1-16 DOI: 10.1080/03057240701803643

Milli Eğitim Bakanlığı (MEB). (2018). Ortaöğretim tarih 9 ders kitabı, Ankara.

MEB (2018). Ortaöğretim tarih 10 ders kitabı. Ankara: MEB.

MEB (2018). Ortaöğretim tarih 11 ders kitabı. Ankara: MEB.

MEB (2018). Ortaöğretim Türkiye Cumhuriyeti Inkılap Tarihi ve Atatürkçülük 12 ders kitabı, Ankara.

MEB (2018). Ortaöğretim tarih dersi (9, 10, 11. Sınıflar) öğretim programı http://mufredat.meb.gov.tr (10.05.2020).

Merriam, B. S. (2015) Nitel araştırma: Desen ve uygulama için bir rehber. Ankara: Nobel.

Muç, K. (2019). Ortaöğretim tarih ders kitaplarında değer aktarım yaklaşımları nelerdir? (Yayımlanmamış Yüksek Lisans Tezi), Marmara Üniversitesi Eğitim Bilimleri Enstitüsü, İstanbul.

Örnek, C. (2020). Soğuk savaş dönemi tarihçiliği ve Türk- İslam sentezi perspektifi. A. Şimşek (Edt.). Türk Tarihçiliğinde Tezler/ Teoriler (s.91-117). İstanbul: Yeni İnsan.

Pamuk, A. (2007). Karakter eğitimi ve sosyal bilgiler öğretimi, I. Ulusal Illköğretim Kongresi'nde sunulan bildiri, Hacettepe Üniversitesi. Ankara, 25.05.2020 tarihinde https://www.academia.edu/541549/Karakter_Eğitimi_ve_Sosyal_Bilgiler_Öğretimi adresinden alınmıştır. 
Pamuk, A. (2009). Vatandaş yetiştirme aracı olarak tarih öğretimi: Orta öğretim düzeyinde öğretmen, öğrenci ve veli görüşleri (Trabzon-Tunceli Örneği). (Yayımlanmamış Yüksek Lisans Tezi). Marmara Üniversitesi Eğitim Bilimleri Enstitüsü. İstanbul

Şimşek A. ve Yazıcı, F. (2013). Türkiye'de tarih eğitiminin dünü, bugünü. TYB Akademi Dil Edebiyat ve Sosyal Bilimler Dergisi, 3(8), s.11-33

Tokdemir, M.A. (2007). Tarih öğretmenlerinin değerler ve değer eğitimi hakkındaki görüşleri. (Yayınlanmış Yüksek Lisans Tezi), Karadeniz Teknik Üniversitesi Sosyal Bilimler Enstitüsü, Trabzon.

Ulusoy, K. (2010). Değer eğitimi; davranışçı ve yapılandırmacı yaklaşıma göre hazırlanan tarih programlarında değer aktarımı, Trakya Üniversitesi Sosyal Bilimler Dergisi, 12(1), s.3251.

Üstel, F. (2016). Makbul vatandaşın peşinde: II. Meşrutiyetten bugüne vatandaşlık eğitimi. İstanbul: İletişim.

Yel, S. ve Aladağ, S. (2009). Sosyal bilgilerde değerlerin öğretimi. M. Safran (Edt.) Sosyal Bilgiler Öğretimi, (s.117-148). Ankara: Pegem Akademi.

Yıldırım. A. ve Şimşek, H. (2013). Sosyal bilimlerde nitel araştırma yöntemleri. (9. Baskı). Ankara: Seçkin.

Yıldırım, T. (2017). Yeni ortaöğretim tarih ders programları ve kitaplarında değerler eğitimi, TurkishStudies,12 (33),557-572. DOI: http://dx.doi.org/10.7827/TurkishStudies.12533 